\title{
Discordant clinical outcomes of congenital Zika virus infection in twin pregnancies
}

\author{
Evolução clínica discordante da infecção congénita do vírus Zika em gestação gemelar \\ Vanessa van der Linden 1,2, Hélio van der Linden Junior ${ }^{3}$, Mariana de Carvalho Leal ${ }^{4,5}$, \\ Epitacio Leite Rolim Filho2,4, Ana van der Linden6, Maria de Fátima Viana Vasco Aragão,8, \\ Alessandra Mertens Brainer-Lima9 ${ }^{9}$ Danielle Di Cavalcanti Sousa Cruz ${ }^{6}$, Liana O. Ventura ${ }^{10,11}$, \\ Telma Lúcia Tabosa Florêncio ${ }^{12}$, Marli Tenório Cordeiro ${ }^{13}$, Silvio da Silva Caudas Neto ${ }^{4}$, Regina Coeli Ramos ${ }^{14}$
}

\begin{abstract}
Congenital Zika syndrome is an emergent cause of a congenital infectious disorder, resulting in severe damage to the central nervous system and microcephaly. Despite advances in understanding the pathophysiology of the disease, we still do not know all the mechanisms enrolled in the vertical transmission of the virus. As has already been reported in other types of congenital infectious disorders in dizygotic twin pregnancies, it is possible that the virus affects only one of the fetuses. In this article, we report on two cases of twin pregnancies exposed to the Zika virus, but with only one of the fetuses affected with microcephaly and brain damage. This indicates the urgent need for more studies regarding the pathophysiology of viral infection and the mechanisms involved in the natural protection against the virus.
\end{abstract}

Keywords: Zika virus; Zika virus infection; twins, dizygotic.

\section{RESUMO}

A síndrome congênita do Zika vírus é uma causa de infecção congênita emergente, resultando em graves danos ao sistema nervoso central e microcefalia. Apesar dos avanços na compreensão da fisiopatologia da doença, ainda não conhecemos todo o mecanismo envolvido na transmissão vertical do vírus. Como já foi relatado em outros tipos de infecções congênitas em gestações gemelares dizigóticas, é possível que apenas um dos fetos seja afetado pelo vírus. Este artigo descreve 2 casos de gestações gemelares expostas ao vírus Zika, onde apenas um dos fetos foi afetado, com microcefalia associado a graves danos no sistema nervoso central. Isso indica a necessidade urgente de mais estudos sobre a fisiopatologia da infecção viral e os mecanismo envolvidos na proteção natural contra o vírus.

Palavras-chave: Zika virus; infecção pelo Zika virus; gêmeos dizigóticos;

Gestational Zika virus (ZIKV) infection has been robustly associated with a well-delimited congenital syndrome including microcephaly and specific neuroradiological abnormalities, defining the congenital Zika syndrome $(\mathrm{CZS})^{1,2,3}$. Other symptoms have also been described in association with the syndrome, such as ophthalmologic lesions, hearing loss and arthrogryposis ${ }^{4,5,6}$. Like other congenital viral infections, only a proportion of gestational ZIKV results in children affected by CZS. Reports of discordant clinical outcomes for twin pregnancies with gestational infections have been reported

${ }^{1}$ Hospital Barão de Lucena, Recife PE, Brasil;

${ }^{2}$ Associação de Assistência à Criança Deficiente (AACD), Recife PE, Brasil;

${ }^{3}$ Centro de Reabilitação Dr. Henrique Santillo, Goiania GO, Brasil;

«Universidade Federal de Pernambuco, Recife PE, Brasil;

${ }^{5}$ Hospital Agamenon Magalhães, Recife PE, Brasil;

${ }^{6}$ Instituto de Medicina Integral Professor Fernando Figueira, Recife PE, Brasil;

${ }^{7}$ Centro Diagnóstico Multimagem, Recife PE, Brasil;

${ }^{8}$ Universidade Mauricio de Nassau, Recife PE, Brasil;

`Universidade de Pernambuco, Recife PE, Brasil;

${ }^{10}$ Fundação Altino Ventura, Recife PE, Brasil;

${ }^{11}$ Hospital de Olhos de Pernambuco (HOPE), Recife PE, Brasil;

${ }^{12}$ UniVision, Recife PE, Brasil;

${ }^{13}$ Centro de Pesquisas Aggeu Magalhães-Fiocruz, Recife PE, Brasil;

${ }^{14}$ Hospital Universitário Oswaldo Cruz, Recife PE, Brasil;

Correspondence: Vanessa van der Linden;AACD Pernambuco, Av. Adv José Paulo Cavalcanti, 155; 50080-810 Recife PE, Brasil; E-mail:vanessavdlinden@hotmail.com Conflict of interest: There is no conflict of interest to declare.

Received 05 February 2017; Received in final form 27 February 2017; Accepted 06 March 2017. 
for cytomegalovirus and toxoplasmosis ${ }^{7,8}$. We describe two cases of twin pregnancy with gestational infection by ZIKV, in which only one fetus was born with CZS.

\section{METHODS}

\section{Data collection}

A standard form was used to collect demographic and clinical data, including the recollection of a rash during pregnancy.

All investigations described were conducted as part of the clinical protocol or clinical indication; no investigations were conducted for research reasons. Informed consent was obtained from the participants or their legally authorized representatives.

\section{Laboratory tests}

Serologic tests were performed on both mother and newborns to exclude the main differential diagnoses of CZS (i.e., other congenital infections that lead to brain calcifications and microcephaly), which are cytomegalovirus, toxoplasmosis, rubella, syphilis and HIV. When cytomegalovirus IgG was present in both mother and child, real-time polymerase chain reaction was performed in urine or blood.

The cerebrospinal fluid (CSF) of patients was tested for IgM antibody capture enzyme-linked immunosorbent assay (ELISA) for ZIKV, following the Center for Disease Control and Prevention (CDC) protocol, as described by Martin et al. ${ }^{9}$ Laboratory confirmation was considered as a positive ZIKV-specific IgM in CSF with capture ELISA, according to the CDC Emergency Use Authorization protocol with reagents by Robert Lanciotti (CDC, Fort Collins, CO, USA), as recently published by Cordeiro et al. ${ }^{10}$

\section{Clinical evaluation}

For clinical evaluation, microcephaly was defined as a head circumference two standard deviations below the mean for gestational age and sex, according to the Fetal International and Newborn Growth Consortium for the 21st Century (Intergrowth-21st) for newborns and the World Health Organization child growth standards for infants $^{11,12}$. Birth weight was classified as appropriate, small or large for gestational age and sex according to the Intergrowth-21st curve ${ }^{11}$.

All the infants underwent neurologic, orthopedic, ophthalmological, and hearing evaluations, including clinical examination and ancillary exams. The infant patients had brain imaging by non-contrasted computerized tomography (CT) and simple radiography of the hips. Clinical assessment of dysphagia was made by a speech therapist. Audiometric screening was carried out by auditory brainstem response audiometry, and confirmed by diagnostic tests (confirmatory frequencyspecific auditory brainstem response with tone burst stimuli and behavioral audiometry) using the routine recommended by the Brazilian Heath Ministry and the American Academy of Pediatrics' Joint Committee on Infant Hearing ${ }^{13}$.

\section{CASE REPORTS}

\section{Patient 1}

A boy, born in 2015 in Recife, State of Pernambuco, from a dizygotic twin pregnancy. His mother had an episode of skin rash associated with itching and fever in the first month of gestation. At the 25th week of pregnancy, microcephaly was diagnosed by obstetric ultrasonography, but no anomaly was detected by this method in the twin brother. Delivery occurred at a gestational age of 37 weeks, with the newborn weighing 2,100 g; the head circumference was $28 \mathrm{~cm}$ (3 SD from the gestational age and sex, classified as severe microcephaly). The patient also presented with craniofacial disproportion, closed anterior fontanelle, exuberant occipital protuberance, redundant scalp skin and a right clubfoot. Brain CT revealed diffuse bilateral reduction of cerebral parenchyma, ventriculomegaly, cortical underdevelopment, multiple calcifications predominantly in the basal ganglia and cortical/subcortical white matter regions, and hypoplasia of the brainstem and cerebellum (Figure 1).

First eye exam (13 days after birth): clear cornea, depth anterior chamber, phakic, isocoria, pathologic red reflex test both eyes. High myopia (-12.00 OD and -9.00 OS), vitreous haze, bilateral staphyloma chorioretinal lesions (sharply demarcated atrophy) involving the posterior pole and optic disc OD and only macula in OS. After three months of age, developed congenital glaucoma OD and underwent surgery.

Last exam (one year old): ocular pressure under control, clear cornea, stable myopia, fundus findings were the same, clear vitreous.

Auditory evaluation by frequency-specific auditory brainstem response and behavioral audiometry detected bilateral profound hearing loss. After an unsuccessful attempt at rehabilitation with hearing aids and speech therapy, a cochlear implant was scheduled for this child.

At seven months of age, he started presenting with spasms in clusters. The pattern of EEG was focal, with discharge in the frontal lobe at first, and at 12 months of age, the EEG presented with multifocal discharge. The seizures were controlled with valproate. At the age of 12 months he presented with neurodevelopmental arrest, with no interaction with the environment and no head control. An X-ray of the hips showed left hip dysplasia.

The development and neurological evaluation of his brother was normal at 10 months of age.

\section{Patient 2}

Dizygotic twins, a girl and a boy, were born in Recife, State of Pernambuco, with a history of maternal fever and rash associated with itching at three months of pregnancy. Microcephaly 

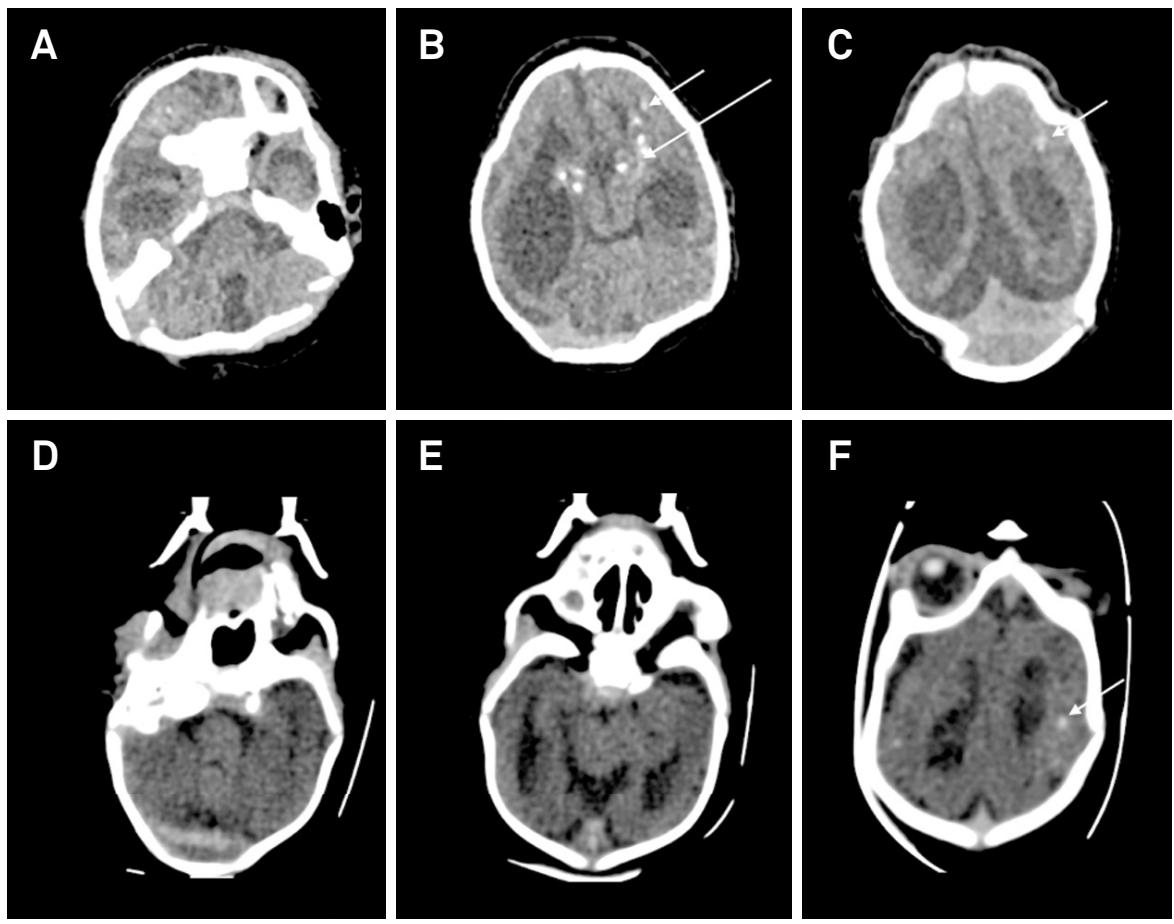

Figure 1. A, B and C are brain computerized tomography from Patient 1 and D, E and F are from Patient 2. A and D show the brainstem and cerebellum hypoplasia; B, C, E and F show diffuse bilateral reduction of cerebral parenchyma, ventriculomegaly and cortical underdevelopment; B, C and F show calcifications in the basal ganglia (long arrow) and cortical/subcortical white matter regions (short arrow).

was diagnosed at 32 weeks of pregnancy by ultrasonography in the female twin. After delivery at 35 weeks, the female newborn had a head circumference of $26 \mathrm{~cm}$ (below 3 SD for the gestational age and sex) and weighed $1,750 \mathrm{~g}$. The same craniofacial findings observed in Patient 1 were present. Brain CT revealed diffuse bilateral reduction of cerebral parenchyma, ventriculomegaly, malformation of cortical development, multiple calcifications in cortical/subcortical white matter regions and mild hypoplasia of the brainstem and cerebellum (Figure 1). The anterior and posterior segments of the eye were normal in the ophthalmological assessment. The auditory evaluation was normal.

Epilepsy was diagnosed at six months of age, with the same seizure pattern, but we are still waiting for the EEG. Her seizures were reduced with levetiracetam. At the last evaluation, at seven months of age, she presented with severe neurodevelopmental delay, with no interaction with the environment and no head control. The X-ray of the hips was normal.

The development and neurological evaluation of her brother were normal at seven months of age.

In these two cases, screening tests for the most common causes of congenital infection (toxoplasmosis, cytomegalovirus, rubella, syphilis and HIV) were negative. The CSF sample was tested by IgM antibody capture ELISA for ZIKV and it was positive. And, in both cases, the unaffected twin was normal on clinical examination, and blood and CSF tests for ZIKV were negative.

Tables 1 and 2 summarize the main findings of the two newborns.

\section{DISCUSSION}

This article describes two twin siblings exposed to the Zika virus during pregnancy, but only one of the siblings presented with a typical picture of CZS. The craniofacial aspects of our patients (Figure 2) were described by Russel et al. as a fetal brain disruption sequence ${ }^{14}$. The fetal brain disruption sequence phenotype is hypothesized to be a result of loss in brain volume and decrease in intracranial pressure, and it is not specific to the etiologic agent. Moore et al. described the fetal brain disruption sequence phenotype related to $\mathrm{CZS}^{15}$.

The brain imaging of the two patients, showing calcifications predominantly in the subcortical region, with abnormalities of cortical development, was consistent with the pattern fully described by Aragão et al. for $\mathrm{CZS}^{3}$. The diagnosis of this syndrome was based on the neuroimaging findings, exclusion of other congenital infections and the presence of positive IgM in the CSF of the two affected children.

Only one patient presented with ophthalmic and auditory abnormalities. Congenital infection due to presumed ZIKV exposure has been shown to be associated with vision-threatening findings, such as the bilateral macular and optic nerve abnormalities seen in the first patient of this study. Glaucoma has been described in one infant from Bahia, Brazil ${ }^{5,16}$.

Congenital infection by ZIKV is a new condition and the real risk of mother-fetus transmission of this virus is still unknown. Nishiura et al. tried to estimate a theoretical risk of microcephaly occurrence from congenital 
Table 1. Clinical findings

\begin{tabular}{|c|c|c|}
\hline \multirow{2}{*}{ Variable } & \multicolumn{2}{|c|}{ Case } \\
\hline & 1 & 2 \\
\hline Sex & M & $\mathrm{F}$ \\
\hline Abnormalities gestational ultrasonography & yes, 25 w & yes, 32 w \\
\hline ZIKV IgM antibody in CSF & positive & positive \\
\hline Gestational age at birth & $36 w$ & $35 w$ \\
\hline Weight at birth (g) & 2100 & 1750 \\
\hline Birth weight for gestational age & Appropriate & Appropriate \\
\hline Head circumference at birth (cm) & 28 & 26 \\
\hline Microcephaly & yes, severe & yes, severe \\
\hline Thoracic circumference at birth (cm) & no data & 24 \\
\hline APGAR - $1 \mathrm{~min} / 5 \mathrm{~min}$ & $9 / 10$ & $9 / 10$ \\
\hline Rash during pregnancy & yes & yes \\
\hline Gestational age of cutaneous rash & 1 month & 3 months \\
\hline Craniofacial disproportion & yes & yes \\
\hline Exuberant occipital protuberance & yes & yes \\
\hline Redundant scalp skin & yes & yes \\
\hline Irritability during the first months of age & no & yes \\
\hline Hyperexcitability & yes & yes \\
\hline Hip dysplasia & yes & no \\
\hline Other malformations & club foot & no \\
\hline
\end{tabular}

M: male; F: female; w: weeks; ZIKV:Zika virus; CSF: cerebrospinal fluid; min: minutes.

Table 2. Neurological findings.

\begin{tabular}{lcc}
\hline Variable & & Patient \\
\hline Age of testing & 1 & 2 \\
\cline { 2 - 3 } Corrected age & 12 mo & 7 mo \\
Head circumference & 11 months & 6 months \\
Microcephaly & $38 \mathrm{~cm}$ & $34 \mathrm{~cm}$ \\
Weight & yes & yes \\
Visual fixation and pursuit & $8020 \mathrm{~g}$ & no \\
Interaction with the environment & no & no interaction \\
Strabismus & no interaction & yes \\
Nystagmus & yes & yes \\
Social smile & yes & no \\
Head control & no & no \\
Sitting without support & no & no \\
Grasp & no & grasping reflex \\
Asymmetric tonic neck reflex & grasping reflex & present \\
Muscle tone & present & Limb hypertonia with pyramidal \\
Dysphagia & and extrapyramidal signs \\
Epilepsy & and extrapyramidal signs & yes, moderate \\
\hline
\end{tabular}

ZIKV and assumed that it could be of at least $14.0 \%{ }^{17}$ For Ellington et al. ${ }^{18}$, following the Puerto Rico outbreak, the risk of microcephaly ranged from $1 \%$ to $13 \%$ for maternal infection in the first trimester, up to $0.7 \%$ in the second trimester, and up to $0.2 \%$ in the third trimester.

There are many reports in the literature about congenital infections in twin pregnancy affecting only one sibling, most of them dizygotic ${ }^{7,8,19,20,21,22}$. Maternal factors related to immunologic competency may explain why some mothers transmit the virus to the fetus, causing neurologic damage, and others do not. However, this cannot explain the differences in the outcomes of the children in twin pregnancies. One possible explanation for this is the differences in fetal susceptibility. Lazzarotto et al. showed that twin fetuses may react differently to primary maternal cytomegalovirus infection, in spite of being exposed to the same maternal influences ${ }^{7}$. A few reports 

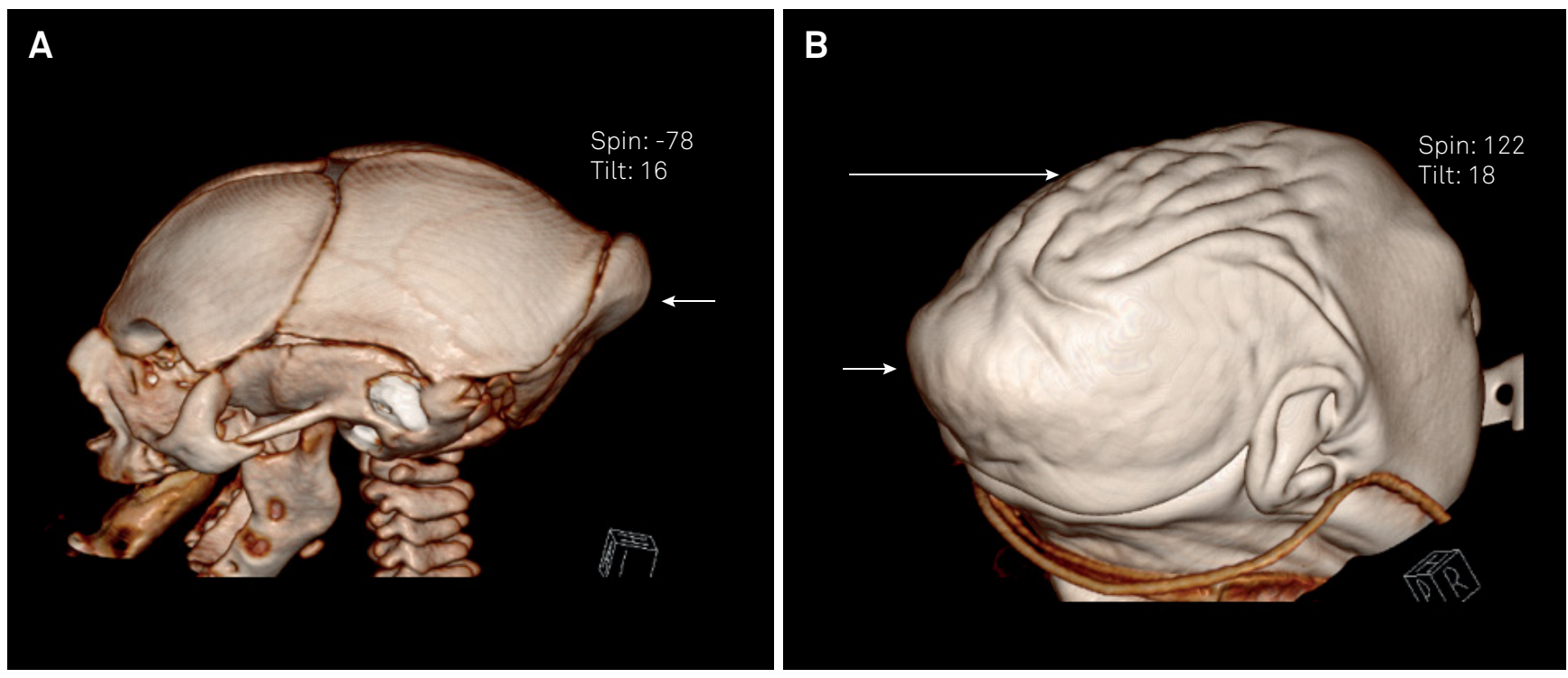

Figure 2. A and B show the computed tomography of the skull with reconstruction, of Patient 1, with the typical phenotype of fetal brain disruption sequence characterized by microcephaly with exuberant occipital protuberance (short arrow) and redundant skin on the scalp (long arrow).

of different outcomes in monozygotic twins in cytomegalovirus-affected pregnancies corroborate this theory ${ }^{232,24}$.

Another explanation is the differences in placental function in dizygotic twin pregnancies. Although the placenta acts as a portal for mother-fetus transmission of viral diseases, it is not completely permeable, as demonstrated by Fowler et al., who found fetal contamination in only $40 \%$ of cases of gestational cytomegalovirus ${ }^{25}$.This placental barrier function can be explained by several mechanisms, but it is still not completely understood how, in various cases of twin pregnancies with viral infection, only one of the fetuses is affected $^{7,26}$. In the patients presented, the placentas were not studied. The comparison of the placentas from the normal and the affected child could throw some light onto the question of distinct outcomes.

Despite the advances in understanding the pathophysiology of the disease, we still do not know all the mechanisms enrolled in vertical transmission of the ZIKV virus. As has already been reported in other types of congenital infectious disorders in dizygotic twin pregnancies, it is possible for the virus to affect only one of the fetuses. This indicates the urgent need for more studies regarding the pathophysiology of the viral infection. Other possible variants, like genetic factors, viral tropism and the placenta barrier could influence the pathophysiology of the CZS and must be investigated in further studies.

There was no pathology study of the placentas in this patient series. This could be important to define whether the virus compromised the placenta of the non-affected child or not. This information is crucial to understand whether the placenta is the most important barrier against the virus invasion, or if intrinsic fetal factors are more important for this particular protection. There is lack of evidence on how exactly the virus disseminates through the pregnant body, how it reaches the fetus, and which type of barrier could influence this mechanism. Further genetic studies may elucidate if there are genes involved in specific protection against external agents.

\section{References}

1. Mlakar J, Korva M, Tul N, Popović M, Poljšak-Prijatelj M, Mraz J N, Popović M, Poljšak-Prijatelj M, Mraz J et al. Zika virus associated with microcephaly. N Engl J Med. 2016;374(10):951-8. https://doi.org/10.1056/NEJMoa1600651

2. Rasmussen SA, Jamieson DJ, Honein MA, Petersen LR. Zika virus and birth defects: reviewing the evidence for casuality. N Engl J Med. 2016;374(20):1981-7. https://doi.org/10.1056/NEJMsr1604338

3. Aragão MFV, Linden V, Brainer-Lima AM, Coeli RR, Rocha MA, Silva PS et al. Clinical features and neuroimaging (CT and MRI) findings in presumed Zika virus related congenital infection and microcephaly: retrospective case series study. BMJ. 2016;353:i1901. https://doi.org/10.1136/bmj.i1901

4. Linden V, Rolim Filho EL, Lins OG, Linden A, Viana MF, Aragão MFVV et al. Congenital Zika syndrome with arthrogryposis: retrospective case series study. BMJ. 2016;354:i3899. https://doi.org/10.1136/bmj.i3899
5. Ventura CV, Maia M, Ventura BV, Linden VV, Araújo EB, Ramos RC et al. Ophthalmological findings in infants with microcephaly and presumable intra-uterus Zika virus infection. Arq Bras Oftalmol. 2016;79(1):1-3. https://doi.org/10.5935/0004-2749.20160002

6. Leal MC, Muniz LF, Ferreira TSA, Santos CM, Almeida LC, Linden $V$ et al. Hearing loss in infants with microcephaly and evidence of congenital Zika virus infection - Brazil, November 2015-May 2016. MMWR Morb Mortal Wkly Rep. 2016;65(34):917-9. https://doi.org/10.15585/mmwr.mm6534e3

7. Lazzarotto T, Gabrielli L, Foschini MP, Lanari M, Guerra B, Eusebi V et al. Congenital cytomegalovirus infection in twin pregnancies: viral load in the amniotic fluid and pregnancy outcome. Pediatrics. 2003;112(2):e153-7. https://doi.org/10.1542/peds.112.2.e153 
8. Thapa R, Banerjee P, Akhtar N, Jain TS. Discordance for congenital toxoplasmosis in twins. Indian J Pediatr. 2009;76(10):1069-70. https://doi.org/10.1007/s12098-009-0208-9

9. Martin DA, Muth DA, Brown T, Johnson AJ, Karabatsos N, Roehrig JT. Standardization of immunoglobulin M capture enzyme-linked immunosorbent assays for routine diagnosis of arboviral infections. J Clin Microbiol. 2000;38(5):1823-6.

10. Cordeiro MT, Pena LJ, Brito CA, Gil LH, Marques ET. Positive IgM for Zika virus in the cerebrospinal fluid of 30 neonates with microcephaly in Brazil. Lancet. 2016;387(10030):1811-2. https://doi.org/10.1016/S0140-6736(16)30253-7

11. Villar J, Cheikh Ismail L, Victora CG, Ohuma EO, Bertino E, Altman DG et al. International Fetal and Newborn Growth Consortium for the 21st Century (INTERGROWTH-21st). International standards for newborn weight, length, and head circumference by gestational age and sex: the Newborn Cross-Sectional Study of the INTERGROWTH-21st Project. Lancet. 2014;384(9946):857-68. https://doi.org/10.1016/S0140-6736(14)60932-6

12. World Health Organization - WHO, Department of Nutrition for Helath and Development. WHO child growth standards: Head circumference-for-age, arm circumference-for-age, triceps skinfold-for-age and subscapular skinfold-for-age: methods and development. Geneva: World Health Organization; 2007.

13. American Academy of Pediatrics, Joint Committee on Infant Hearing. Year 2007 position statement: principles and guidelines for early hearing detection and intervention programs. Pediatrics. 2007;120(4):898-921. https://doi.org/10.1542/peds.2007-2333

14. Russell LJ, Weaver DD, Bull MJ, Weinbaum M, Opitz JM. In utero brain destruction resulting in collapse of the fetal skull, microcephaly, scalp rugae, and neurologic impairment: the fetal brain disruption sequence. Am J Med Genet. 1984;17(2):509-21. https://doi.org/10.1002/ajmg.1320170213

15. Moore CA, Staples JE, Dobyns WB, Pessoa A, Ventura CV, Fonseca EB et al. Characterizing the pattern of anomalies in congenital Zika syndrome for pediatric clinicians. JAMA Pediatr. 2017;171(3):288-95 https://doi.org/10.1001/jamapediatrics.2016.3982

16. Freitas BP, Ko Al, Khouri R, Mayoral M, Henriques DF, Maia M et al. Glaucoma and congenital Zika syndrome. Ophthalmology. 2017;124(3):407-8. https://doi.org/10.1016/j.ophtha.2016.10.004
17. Nishiura H, Mizumoto K, Rock KS, Yasuda Y, Kinoshita R, Miyamatsu Y. A theoretical estimate of the risk of microcephaly during pregnancy with Zika virus infection. Epidemics. 2016;15:66-70. https://doi.org/10.1016/j.epidem.2016.03.001

18. Ellington SR, Devine O, Bertolli J, Martinez Quiñones A, Shapiro-Mendoza CK, Perez-Padilla J et al. Estimating the number of pregnant women infected with Zika virus and expected infants with microcephaly following the Zika virus outbreak in Puerto Rico, 2016. JAMA Pediatr. 2016;170(10):940-5. https://doi.org/10.1001/jamapediatrics.2016.2974

19. Martino M, Tovo PA, Galli L, Caselli D, Gabiano C, Mazzoni PL et al. HIV-I infection in perinatally exposed siblings and twins: the Italian register for HIV infection in children. Arch Dis Child. 1991;66(10):1235-8. https://doi.org/10.1136/adc.66.10.1235

20. Barlow KM, Mok JY. Dizygotic twins discordant for HIV and hepatitis C virus. Arch Dis Child. 1993;68(4):507. https://doi.org/10.1136/adc.68.4.507

21. Egaña-Ugrinovic G, Goncé A, García L, Marcos MA, López M, Nadal A et al. Congenital cytomegalovirus infection among twin pairs. J Matern Fetal Neonatal Med. 2016;29(21):3439-44. https://doi.org/10.3109/14767058.2015.1130818

22. Tomasik T, Zawilińska B, Pawlik D, Ferek J, Ferek J, Wójtowicz A et al. [Congenital cytomegaly in one twin: a case report]. Med Wieku Rozwoj. 2012;16(3):252-60. Polish.

23. Seguin J, Cho CT. Congenital cytomegalovirus infection in one monozygotic twin. JAMA. 1988;260(22):3277. https://doi.org/10.1001/jama.1988.03410220061021

24. Wu HY, Huang SC, Huang HC, Hsu TY, Lan KC. Cytomegalovirus infection and fetal death in one monozygotic twin. Taiwan J Obstet Gynecol. 2011;50(2):230-2. https://doi.org/10.1016/j.tjog.2011.01.008

25. Fowler KB, Stagno S, Pass RF, Britt WJ, Boll TJ, Alford CA. The outcome of congenital cytomegalovirus infection in relation to maternal antibody status. N Engl J Med. 1992;326(10):663-7. https://doi.org/10.1056/NEJM199203053261003

26. Fisher S, Genbacev O, Maidji E, Pereira L. Human cytomegalovirus infection of placental cytotrophoblasts in vitro and in utero: implications for transmission and pathogenesis. J Virol. 2000;74(15):6808-20. https://doi.org/10.1128/JVI.74.15.6808-6820.2000 